\title{
Seryjność i nieseryjność serii wydawniczych
}

\section{Wprowadzenie}

B ogactwo oferty wydawniczej i stosowanych strategii wydawniczych $\mathbf{B}_{\mathrm{z}}$ jednej strony jest plusem, gdyż rynek książki staje się ciekawy, z drugiej zaś swoją mnogością przysparza problemów w analizowaniu tego rynku. Skąd te dysfunkcje? Transformacja polityczna i gospodarcza po 1989 r. spowodowała m.in. uwolnienie rynku książki i zmiany technologiczne w procesie wydawniczym, natomiast wskazania marketingowe sprawiły, że na rynku książki zapanowała dowolność działań ${ }^{1}$. Wielorodzajowość ukazujących się publikacji, pojawiające się i znikające wydawnictwa sprawiają, iż trudno o stabilizację i ich kategoryzację.

Tworzenie nowego modelu rynku wydawniczego, opartego na konkurencji, wymusiło różnorodność. Okładka książki nie powinna być nijaka, smutna i zawierać wyłącznie tytułu: „Większość jest za tym, aby okładka była barwna i atrakcyjna"2. Książka naukowa przechodzi przemiany, musi je przejść, gdyż jej sprzedaż przysparza coraz więcej trudności ${ }^{3}$.

* Studentka II roku uzupełniających studiów magisterskich informacji naukowej i bibliotekoznawstwa w Instytucie Informacji Naukowej i Bibliologii Uniwersytetu Mikołaja Kopernika w Toruniu.

1 Por. J. Walewska, Raport o ksiq̨żce akademickiej i naukowej, Warszawa 2001, s. 13.

2 Cz. Dejnarowicz, Literatura naukowa - uczeni - wydawcy, Warszawa 1980, s. 257.

${ }_{3}$ Por. Ł. Gołębiewski, K. Frołow, Rynek książki w Polsce 2008. Wydawnictwa, Warszawa 2008, s. 121-122. 
Wydawcy szybko uczą się marketingu ${ }^{4}$, który wymusza na nich dążenie do oryginalności. Bogactwo wydawnictw staje się problemem ich niejednolitości, a to powoduje trudności kategoryzacyjne i interpretacyjne podczas podziału ukazujących się publikacji. Artykuł ten jest próbą analizy trzech serii wydawniczych („Klasyka Mniej Znana”, „Literatura i Kultura Popularna”, „Acta Universitatis Wratislaviensis”), wskazania odmienności wynikających z publikowania innego typu tekstów oraz z całkiem innego podejścia do założeń wybranej strategii wydawniczej. Serie te wydają całkowicie odmienne teksty, są wyraźnie od siebie różne, ale wszystkie pretendują do tej kategorii wydawnictw.

Czasopisma, publikacje zwarte, cykle i serie wydawnicze ${ }^{5}$ - tak kształtuje się główna typologia wydawanych tytułów. Skąd zatem problemy typologiczne? Czasopisma - szczególnie naukowe - ewoluują, są wydawane jako tomy monograficzne, wyglądem przypominające publikacje zwarte. Z kolei pojęcie cyklu i serii wydawniczej stosuje się w języku potocznym właściwie zamiennie. Opierając się na definicji Barbary Kalisz, która zauważa, że seria to: „ciąg samoistnych publikacji o nieokreślonym terminie zakończenia edycji, związany wspólną problematyką, wspólnym tytułem i (lub) znakiem uwidocznionym na okładce i karcie tytułowej, jednolitym formatem oraz szatą graficzna"6, można stwierdzić, iż publikacje aspirujące do miana serii często - w myśl tej definicji - seriami nie są. Do elementów serii - jakie wymienia Kalisz - należy dodać możliwość wystąpienia podtytułu, numeracji lub datowania ${ }^{7}$. Jednak czynnikami decydującymi o tym, że dany typ publikacji zaklasyfikowano jako serię, będą ISSN ${ }^{8}$ i intencja wydawcy. Pojęcia cyklu wydawniczego, który ma z góry określony koniec, i kolekcji ${ }^{9}$ należy traktować jako synonimy. Bogactwo serii jest dodatkowym wyzwaniem dla badaczy próbujących dokonać ich klasyfikacji. Naukowe wydawnictwo Universitas wydawało i wydaje wiele serii wydawniczych, m.in.: „Lektury Polonistyczne”, „Biblioteka Polska”, „Klasyka

${ }^{4}$ O problemach wydawców książek naukowych z marketingiem pisze J. Walewska, dz. cyt., s. 43-45.

${ }_{5}$ Por. K. Narojczyk, Dokument elektroniczny i jego opis bibliograficzny w publikacjach humanistycznych, Olsztyn 2005, s. 29-30.

${ }^{6}$ Słownik wydawcy, oprac. B. Kalisz, Warszawa 1997, s. 176.

7 Elementy serii podane za K. Narojczyk, dz. cyt., s. 30.

${ }^{8}$ Zgodnie z Instrukcją Międzynarodowego Znormalizowanego Numeru Książki ISBN nie jest nadawany zasobom ciągłym. Serie bez określonego zakończenia oznacza się numerami ISSN.

${ }_{9} 0$ kolekcjach wydawniczych dla dzieci piszą Ł. Gołębiewski, K. Frołow, dz. cyt., s. 94. 
Polskiej Myśli Humanistycznej”, „Horyzonty Nowoczesności” czy też „Klasyka Mniej Znana"10.

\section{Klasyka klasyki...}

Inspiracją do powstania tej ostatniej była idea, aby dzieła wyjątkowe, oryginalne, wielowymiarowe znalazły nowego czytelnika, a raczej, aby ktoś o nich usłyszał. Wiąże się to $\mathrm{z}$ faktem, że - jak już sama nazwa serii wskazuje - ukazywały się w niej teksty ambitne, choć nieznane ${ }^{11}$. Wśród autorów tekstów literackich spotykamy m.in. Włodzimierza Perzyńskiego, Mieczysława Romanowskiego czy też Tadeusza Rittnera. Pomysłodawcy serii chcieli w ten sposób ocalić od zapomnienia utwory doniosłe, które zmieniły postrzeganie literatury, a które dla współczesnego czytelnika są niedostępne, gdyż wcześniejsze wydania tych dzieł znajdują się najczęściej w księgozbiorach bibliotek specjalistycznych i naukowych. A czasem i w tych miejscach są unikatami.

Publikacje są bardzo dobrze dobrane, jedyne w swoim rodzaju, swoiste perełki literatury, które miały szansę zaistnieć na nowo w świadomości czytelnika i z powodzeniem mogły konkurować z bestsellerami współczesnej literatury. Dobór tytułów odbywał się na podstawie napływających zgłoszeń i zapytań, czy dana lektura powinna wejść w skład serii, oraz na podstawie konsultacji z polonistami i ze specjalistami z zakresu wybranych epok. Wiele z tych pozycji to książki zalecane przez autorów podręczników do nauki języka polskiego jako lektury uzupełniające, a ogromna większość, jeśli nie wszystkie, to tytuły znajdujące się na listach lektur studentów filologii polskiej.

Wydawnictwo Universitas obok „Klasyki Mniej Znanej” publikowało pokrewną serię - „Klasykę...”. Nowa edycja okazała się bliźniaczą - ta sama koncepcja typograficzna oraz identyczne założenia, dotyczące wydawanych publikacji, zaowocowały utożsamieniem serii ze sobą, a właściwie zlaniem się tych dwóch projektów w jeden. Książki „Klasyki...” były traktowane jako należące do „Klasyki Mniej Znanej”, a sama nazwa - jako

10 Por. Ł. Gołębiewski, Rynek książki w Polsce, Warszawa 2002, s. 415-416.

11 O serii „Klasyka Mniej Znana” pisali m.in. K. Szczuka, Seria „Klasyka mniej znana”. Gazeta Wyborcza [on-line] z dnia 10.07.2002 [dostęp 15 lipca 2009]. Dostępny w World Wide Web: http://wyborcza.pl/1,75517,926778.html; C. Polak, Klasyka mniej znana. Praca zbiorowa. Gazeta Wyborcza [on-line] z dnia 21.04.2002 [dostęp 15 lipca 2009]. Dostępny w World Wide Web: http://wyborcza.pl/1,75517,800918.html. 
jej krótsza forma. Dla zwykłego czytelnika dowodem na to, że jednak są to rozłączne serie, był komunikat wydawcy zamieszczony na trzeciej stronie okładki jednej z publikacji, wraz z informacjami dotyczącymi dystrybucji: „Co kwartał stali prenumeratorzy serii «Klasyka Mniej Znana» otrzymają od wydawnictwa prezent w postaci książki z serii «Klasyka...»"12.

Wydawnictwo postawiło sobie bardzo szlachetny cel spopularyzowania klasyki literatury, dotychczas odsuniętej w niepamięć, jednak okazało się to trudniejsze, niż pierwotnie zakładano. Oficyna w 2002 r. wydała w serii 59 tytułów. Zadaniem na rok następny było opublikowanie kolejnych 20 . Wydawnictwo zastrzegło sobie prawo zmiany $10 \%$ tytułów i tak też się stało. Nie wszystkie zaplanowane publikacje ujrzały światło dzienne. W zdecydowanej większości egzemplarzy wykorzystano papier niskiej klasy i druk, którego jakość sprawiała trudności w odczytywaniu tekstu. Użyto, poza czarną, zielonej i fioletowej farby drukarskiej. Poza tym wartość książek obniżał brak rysu historycznoliterackiego. Krytyczny wstęp nie musiał być tak obszerny jak w literackiej serii „Biblioteka Narodowa", ale powinien przynajmniej pozwolić czytelnikowi, który nie zajmuje się zawodowo literaturą, zorientować się w charakterze epoki, w jakiej powstało dzieło, w sylwetce autora i w tematyce utworu. Zamiast takiego wstępu niektóre z publikacji zawierały na odwrocie strony przedtytułowej biogram autora lub notatkę genologiczną, jednak informacje te nie były zamieszczane regularnie. Informację na temat fabuły drukowano na czwartej stronie okładki, w postaci fragmentu tekstu, nawiązującego do tytułu lub wyjaśniającego go. Czasem na odwrocie strony redakcyjnej znajdował się krótki tekst opisujący tematykę dzieła i utworu, jednak i te wiadomości zamieszczano niesystematycznie. Poza tym niektóre z tekstów były przedrukami z serii „Biblioteka Narodowa”, inne natomiast pochodziły ze słabszych wydań, co wiązało się z błędami tekstologicznymi.

„Klasyka Mniej Znana” zawierała elementy identyfikujące serię wydawniczą. Miała sprecyzowaną i ograniczoną tematykę publikacji, mogących wejść w jej skład. Format publikacji ujednolicono $-20 \times 13,5 \mathrm{~cm}$ - jednorodność można zauważyć także w formie szaty graficznej. Okładkę podzielono na dwie części, mające indywidualnie dobraną kolorystykę. Publikacje nie były opatrzone wspólnym logo lub znakiem serii. $\mathrm{Na}$ okładce, jak już wspomniano, podzielonej na pół, w części środkowej każ-

12 Uwaga zamieszczona na trzeciej stronie okładki powieści M. D. Krajewskiego, Wojciech Zdarzyński życie i przypadki swoje opisujący, Kraków 2002. 
dej pozycji umieszczano imię i nazwisko autora oraz tytuł wydawanego dzieła. W prawym górnym rogu okładki każdy z wydawanych tytułów miał fotografię - element graficzny związany z treścią lub charakteryzujący dzieło, i tak np. na okładce Powieści gotyckich Zygmunta Krasińskiego ${ }^{13}$ znalazło się zdjęcie czaszki, natomiast Wojciech Zdarzyński autorstwa Mikołaja Dymitra Krajewskiego ${ }^{14}$ został opatrzony zdjęciem stylowej lampy. W lewym dolnym rogu okładki znalazła się nazwa wydawnictwa. Grzbiety publikacji zawierały informację o tytule i autorze dzieła. Na czwartej stronie okładki, u dołu, Universitas umieścił logo, obok którego po lewej znajduje się adres strony internetowej wydawcy, po prawej zaś kod kreskowy i ISBN. Na trzeciej stronie okładki wymieniono publikacje polecane, należące do serii, lub tytuły, które wkrótce się ukażą. Czwórka tytułowa we wszystkich pozycjach wyglądała identycznie - pierwsza strona zawierała, wyjustowane do prawej strony, nazwisko autora i tytuł, na kolejnej wydawca umieścił, jak już wspomniano - nieregularnie - albo informacje o autorze, albo o dziele. Na stronie tytułowej zamieszczono nazwę serii, pełną tytulaturę oraz miejsce wydania. Ostatnią ze stron czwórki jest strona redakcyjna, zawierająca dane copyright, jak również informacje o tym, z jakiego wydania jest to przedruk. Stałym elementem był także komunikat tekstologiczno-edytorski wydawcy, informujący, że pisownia utworu została zmodernizowana według współczesnych zasad interpunkcji i ortografii. Strona redakcyjna zawiera także informację o ISBN, dane osób projektujących okładkę oraz niesystematycznie - imiona i nazwiska korektorów. Seria nie miała numeru ISSN, nie była też numerowana. Na stronie redakcyjnej zabrakło danych osób odpowiedzialnych za przygotowanie cyklu. $\mathrm{W}$ publikacjach nie zamieszczono również informacji typowych dla metryczki książki - nie ma roku wydania, który jest zastąpiony rokiem copyright. Na ostatniej stronie pozycji, u dołu, znalazła się informacja o zakładzie poligraficznym - krakowskiej Drukarni GS, w której zostały odbite wszystkie publikacje należące do serii. Wydawnictwo na stronach „Klasyki Mniej Znanej” ograniczyło się do promocji książek tylko i wyłącznie w niej wydanych, nie informowało o innych publikacjach wydawanych przez Universitas.

Na dodatkowych stronach poświęconych kanałom dystrybucji wydawca zawarł informacje o ofertach specjalnych dla polonistów, instytucji naukowych i bibliotek. Propozycja była korzystna finansowo, wiąza-

\footnotetext{
${ }^{13}$ Z. Krasiński, Powieści gotyckie, Kraków 2003, s. 97.

14 M. D. Krajewski, dz. cyt., s. 118.
} 
ła się ze zniżką 15-20\%. Jeśli odbiorca decydował się na otrzymywanie książek raz na pół roku, Universitas pokrywał koszty wysyłki.

Wydawnictwo miało kłopoty ze sprzedażą swoich publikacji, dlatego też ich głównym dystrybutorem stały się księgarnie taniej książki. Przekonanie, że dobra literatura obroni się sama, tym razem nie sprawdziło się. Choć Universitas wydawał pozycje wartościowe, nie znalazły się one jednak na listach bestsellerów. Dobrze się stało, że oficyna przypomniała „perły z lamusa”. „Klasyka Mniej Znana” oraz „Klasyka...” to typowe serie literackie. Wspólne założenie wydawnicze i konsekwencja w formie publikowanych książek sprawiają, że odbiorca i badacz nie mają problemów interpretacyjnych. Podobnie jest z serią wydawaną przez Wydawnictwo Uniwersytetu Wrocławskiego w ramach „Acta Universitatis Wratislaviensis” - „Literatura i Kultura Popularna”.

\section{Klasyka tradycyjności...}

Seria Uniwersytetu Wrocławskiego była odpowiedzią na rodzące się zainteresowanie kulturą popularną wśród przedstawicieli środowiska naukowego. Kultura masowa może być polem badawczym dla kulturoznawców, socjologów, literaturoznawców czy też medioznawców. Bezpośrednim impulsem do powołania tej serii było zawiązanie się wśród wrocławskich filologów, pracujących w Instytucie Filologii Polskiej, zespołu zajmującego się kwestiami obiegu literatury popularnej. Krąg badaczy nie był jednak ścisły, a do wrocławskiego środowiska zaczęły napływać teksty z innych ośrodków naukowych. Wydawca charakteryzował celowość powstania „Literatury i Kultury Popularnej” jako: „swoistej «trybuny», otwartej dla różnych orientacji i koncepcji badawczych, stwarzającej szansę dyskutowania zarówno szerokich zagadnień metodologicznych, jak i szczegółowych wyników badań tak ze ściśle pojmowanego zakresu literatury i kultury popularnej, jak i jej szeroko rozumianych kontekstów"15.

Omawiana seria to forum przeznaczone dla osób zajmujących się kulturą masową. Wydawnictwo miało ambicję bycia cykliczną publikacją skierowaną do naukowców i tworzoną przez naukowców i to się udało. Cykl zaczął ukazywać się w 1991 r.; nadano mu 1205 numer serii „Acta

${ }^{15}$ Literatura i Kultura Popularna, t. 1, pod red. M. Staniszewskiej, Wrocław 1991, s. 5-6. 
Universitatis Wratislaviensis”16. Każdy tom podserii („Literatura i Kultura Popularna") był oznaczony kolejnym przypadającym na niego numerem „Act”. Części ukazywały się nieregularnie - czasem z rocznymi czy dwuletnimi przerwami. W 1992 r., kiedy wydawcy mieli dużą ilość zebranego materiału, ukazały się 2 tomy. W przeciągu całego okresu wydawania drukowano w dwóch firmach - w Drukarni Uniwersytetu Wrocławskiego i Wrocławskiej Drukarni Narodowej. Skład był wykonywany w Zakładzie Usług Wydawniczych - Comped, w Pracowni Składu Komputerowego TYPO-GRAF lub przez Beatę Jarczyńską.

„Literatura i Kultura Popularna” jest serią naukową, zaopatrzoną w pełen aparat krytyczny, typowy dla tego rodzaju publikacji: spis treści (w I tomie na początku, w kolejnych jako ostatnie strony wydawnictwa) czy streszczenia artykułów ${ }^{17}$. Każdy artykuł zaczyna się od nowej strony, poprzedzonej wakatem. Zaopatrzony jest w komplet informacji bibliograficznych. Niektóre tomy zawierają indeksy nazwisk (VII, VIII, IX), bibliografię na końcu artykułów (XII) czy też bibliografię zawartości (X). Streszczenia, jeśli występują, to są napisane w języku niemieckim. Początkowo nakład sięgał 300 egzemplarzy $(300+50)$, od tomu III zwiększono go do $350(350+50)$.

Na podstawie informacji podawanych przez oficynę na stronie redakcyjnej można z łatwością prześledzić zmiany na rynku książki. W pierwszych tomach, wydawanych na początku lat 90 ., wydawca podawał informacje o liczbie arkuszy wydawniczych czy też o jakości papieru wykorzystanego do druku, później już zaniechano zamieszczania tych wiadomości. Tendencję tę można zaobserwować wśród wszystkich oficyn wydawniczych tamtego okresu, w którym wolny rynek książki dopiero się konstruował. W I tomie wydawca podał, że na jego publikację zużyto 11,90 arkuszy wydawniczych, w II zaś 11,50. Do wydrukowania pierwszego tomu serii wykorzystano papier offsetowy klasy III o gramaturze 70. Później tych danych nie zamieszczano.

Seria jest wydawana konsekwentnie i schematycznie pod względem formalnym. Zmiana szaty graficznej, z pierwotnej utrzymanej w kolorze żółtym, nastąpiła w tomie IV i do ostatniego tomu, wydanego w 2008 r.,

16 Por. Serie [on-line]. Wydawnictwo Uniwersytetu Wrocławskiego [dostęp 15 lipca 2009]. Dostępny w World Wide Web: http://www.wuwr.com.pl/F-seriaSzczeg.asp?id$\mathrm{S}=13$.

17 O strukturze książki naukowej i o elementach świadczących o naukowości publikacji pisze Cz. Dejnarowicz, dz. cyt., s. 224-230. 
pozostała taka sama. W 1994 r. jednolitą żółtą okładkę, na której umieszczano tytulaturę oraz dane bibliograficzne, zastąpiła okładka czarna, opatrzona tytułem serii. Wydawca wykorzystał do tego pomarańczowy kolor pisma szeryfowego. Strona tytułowa jest bliźniaczym odbiciem okładki. Szata graficzna, zarówno zewnętrzna, jak i wewnętrzna wydawnictwa, jest konsekwentna. Zmiany w edytowaniu artykułów można dostrzec dwukrotnie: w tomie V, kiedy to nad pierwszymi stronami tekstów, zawierającymi dane bibliograficzne, pojawiła się elipsa, w której środek wpisano tytuł wydawnictwa, pełną numerację, miesiąc i rok wydania; oraz w tomie VII, gdy wydawca dodał do notki autorskiej afiliację. Zmiany w graficznym opracowaniu serii ograniczają się do niesystematycznego umieszczania logo wydawnictwa, numeru ISSN czy też ceny. I tak w tomie IX sygnet jest umieszczony w lewym rogu czwartej strony okładki, natomiast już w tomie XII sygnet jest wyśrodkowany, umieszczony u dołu tej strony. Wydawca niesystematycznie - na czwartej stronie okładki - zamieszczał ISBN.

Urozmaiceniem dla badacza oraz bibliotekarza jest ISSN serii, początkowo jeden (ISSN 0239-6661), a od tomu III dwa (nowy ISSN 0867-7441). Pierwszy ISSN, początkowo zarezerwowany wyłącznie dla serii związanej z teatrem, rozprzestrzenił się na inne publikacje ${ }^{18}$, co zaowocowało utożsamianiem go z ISSN „Act”. Drugi nadany ISSN jest już oficjalnym numerem serii i przypisany wyłącznie do niej. ISBN jest indywidualny dla każdego z tomów.

Jak wiele publikacji, również tę potraktowano jako nośnik informacji o innych seriach wydawniczych, ukazujących się w ramach „Act”. Wydawca w I tomie zamieścił wykaz serii ukazujących się na poszczególnych wydziałach Uniwersytetu Wrocławskiego. W ramach Wydziału Filologicznego, z którym oficyna współpracowała przy wydaniach kolejnych tomów serii, ukazały się m.in.: „Bibliotekoznawstwo”, „Anglica Wratislaviensia” czy też „Onomastica Slavogermanica”. Na trzeciej bądź czwartej stronie okładki wydawnictwo zamieszczało informację o kolportażu kolejnych tomów serii lub innych publikacji uniwersytetu.

Dwa tomy z tej serii (t. IV i t. X) były wyjątkowe. Tom IV okazał się jedynym tomem monograficznym w serii - pod redakcją Tadeusza Żabskiego wydano Słownik literatury popularnej. Zeszyt próbny. Publikacja miała być źródłem wiadomości dla osób niezwiązanych zawodowo z li-

${ }_{18}$ Ten ISSN ma np. publikacja: Studia z teorii polityki, pod red. A. W. Jabłońskiego, L. Sobkowiaka, Wrocław 1998. 
teraturoznawstwem i kulturoznawstwem. Natomiast dla badaczy miała być pobudką do dyskusji nad Słownikiem. Redaktor w Słowie wstępnym zaznaczył, że hasła zebrano przypadkowo, gdyż prace nad tomem jeszcze nie zostały skończone. Słownik nie ograniczył się do jednego typu haseł, wręcz przeciwnie - znajdowały się w nim hasła ogólne, osobowe, gatunkowe, tytułowe czy też tematyczne, które uporządkowano w układzie systematycznym ${ }^{19}$. Próby zredagowania Słownika zakończyły się sukcesem w 1997 r., kiedy to ukazał się Słownik literatury popularnej wydany przez Towarzystwo Przyjaciół Polonistyki Wrocławskiej ${ }^{20}$. Wydanie drugie poprawione i uzupełnione ukazało się w 2006 r. nakładem Wydawnictwa Uniwersytetu Wrocławskiego. Drugą edycję Słownika opublikowano w ramach „Acta Universitatis Wratislaviensis" pod numerem $2885^{21}$.

Jubileuszowy tom X ukazał się w 2002 r. W Słowie wstępnym redaktorzy przypomnieli początkowe założenia serii, wymienili osoby współpracujące z wydawnictwem, dokonali podsumowania dotychczas opublikowanych tomów. Zauważyli również rozwijającą się nową tendencję w badaniach kultury popularnej - mianowicie, że młodzi naukowcy bardzo chętnie sięgają po tematy z gier planszowych i komputerowych oraz z Internetu.

Redaktorką ostatniego tomu wydanego w 2008 r. została Anna Gemry. Seria pod jej przewodnictwem nie zmieniła charakteru. Stabilność i przejrzystość wydawnictwa została podtrzymana. „Seryjność” tej serii nie pozostawia wątpliwości - taka sama szata graficzna, wspólny tytuł i numeracja, jednolitość tematyki publikacji oraz nieokreślony termin zakończenia wydania sprawiają, że czytelnik i bibliotekarz, katalogujący daną serię, nie czują się zagubieni.

Choć warto zauważyć, że w praktyce bibliotecznej wyszukiwarki on-line katalogów w bibliotekach wyszukują nazwę serii jako sensu stricto serię oraz jako czasopismo. Takie podwójne wyszukiwanie bibliotekarze wprowadzają dla niewprawionych czytelników, którzy bardzo często mylą oba typy publikacji. Dużo więcej trudności interpretacyjnych przysparzają tomy monograficzne wydawane w serii „Acta Universitatis Wratislaviensis". s. 3-4.

19 Słownik literatury popularnej. Zeszyt próbny, pod red. T. Żabskiego, Wrocław 1994,

20 Słownik literatury popularnej, pod red. T. Żabskiego, Wrocław 1997, s. 767.

${ }^{21}$ Słownik literatury popularnej, pod red. T. Żabskiego, wyd. 2 popr. i uzup., Wrocław 2006. 


\section{Klasyczna nowość}

\iewątpliwie „Acta” należą do jednych z ciekawszych wśród polonistycznych czasopism i serii wydawniczych, a ich oryginalność formalna czyni je intrygującymi pod względem bibliotekarskim. Seria obejmuje prace naukowe publikowane przez Wydawnictwo Uniwersytetu Wrocławskiego, dotyczące szeroko pojętego literaturoznawstwa. W jej skład wchodzą numerowane tomy monograficzne. Numeracja „Act”, które zaczęły ukazywać się w 1962 r., została przejęta z „Zeszytów Naukowych Uniwersytetu Wrocławskiego. Seria A, Prace Literackie”. „Zeszyty” te ukazywały się w latach 1956-1961. „Acta” stanowiące ich kontynuację uznawano za czasopismo, wydające tomy monograficzne. Natomiast wydawca wbrew tradycji traktował „Acta” jako serię, choć one z zewnątrz ani czasopisma, ani serii nie przypominały. Zaglądając do wnętrza „Act”, można podtrzymać wcześniej postawioną tezę, że ich typologia jest jedną z bardziej skomplikowanych.

Poszczególne tomy mają ISBN i wspólny ISSN. W niektórych publikacjach na stronie redakcyjnej nie wymieniono redaktorów odpowiedzialnych za serię. Na stronie przedtytułowej podano wyłącznie nazwę serii oraz numer publikacji, czasem informację tę zamieszczano na stronie redakcyjnej. „Acta” nie mają również stałego miejsca druku. Poza Wrocławską Drukarnią Naukową PAN im. Stanisława Kulczyńskiego są drukowane również w Drukarni Uniwersytetu, jak i w zakładach prywatnych. Tomy do druku są przygotowywane zarówno przez Wydawnictwo Uniwersyteckie, jak i przez inne firmy. Publikacje były zaopatrywane w różnorodny aparat krytyczny - od pozycji najbardziej ubogich, niezawierających żadnego z elementów, składających się na wymogi publikacji naukowej, poprzez wydawnictwa zawierające wyłącznie „Komentarze” i „Spis ilustracji”22, aż do publikacji ${ }^{23}$, których spisy uzupełniające są bardzo bogate ("Noty biograficzne uczestników rozmów”, „Bibliografia”, „Spis ilustracji”, „Streszczenia”, „Indeks nazwisk”, „Indeks teatrów, zespołów i ośrodków”, „Indeks spektakli i projektów teatralnych", „Indeks festiwali i przeglądów”).

W pozycjach należących do serii brak spójnej koncepcji typograficznej. Okładki nie mają jednolitego opracowania graficznego, brak również spójnego pomysłu edytorskiego. Każdy tom jest różny od poprzedniego

${ }^{22}$ Staropolskie poematy myśliwskie. Antologia, wyb. i oprac. W. Dynak, J. Sokolski, Wrocław 2007, s. 242.

${ }^{23}$ M. Gołaczyńska, Wrocławski teatr niezależny, Wrocław 2007, s. 253. 
i zarazem następnego. Tomy mają nieujednolicony format, są oprawiane w okładki twarde lub broszurowe. Wszystkie publikacje są broszurowane trwale, ale sposób broszurowania jest różnorodny - jedne są szyte, inne zaś klejone. Szeroka tematyka wymaga różnego podejścia do wydawanej książki. Tak jest właśnie w tym przypadku - niektóre z wydanych tytułów są zaopatrzone w bardzo bogate ilustracje, inne zaś są ich w ogóle pozbawione. Jedynym znakiem łączącym pozycje w serii jest logo wydawnictwa (a nie znak graficzny serii) umieszczone na grzbiecie i w lewym dolnym rogu lub na środku czwartej strony okładki oraz nazwa serii, która nie ma swojego stałego miejsca.

Taki brak spójności może wynikać z faktu, że publikacje te nie mają wspólnej polityki finansowej. Aby wydać niektóre tomy, należało szukać dofinansowania np. z Urzędu Miasta ${ }^{24}$. W ramach „Act” - serii uniwersyteckiej - są wydawane publikacje należące do innych serii. Omawiając te wydawnictwa, należy pamiętać o tym, aby wydzielić serię główną i podserię publikacji.

W obrębie serii można znaleźć wydawnictwa wielotomowe wydane pod tym samym numerem. Tak jak już wcześniej wspomniano, w „Actach” ukazują się również inne serie, np. Dramat - Teatr redagowana przez Janusza Deglera, obejmująca prace poświęcone historii teatru i problemom teatrologicznym, Studia Generalne. Seminaria Interdyscyplinarne pod redakcją Janiny Gajdy-Krynickiej i Adama Jezierskiego. Oba tytuły, poza głównym numerem „Acta Universitatis Wratislaviensis”, są dodatkowo numerowane w swoim obrębie.

„Acta” to bardzo kłopotliwy nabytek dla bibliotek. Bardzo pojemną treściowo serię trudno klasyfikować. W ramach „Act” ukazał się m.in. podręcznik ${ }^{25}$ i słownik ${ }^{26}$. Ponieważ, jak wspomniano, seria jest kontynuacją „Zeszytów Naukowych”, była więc kategoryzowana jako czasopismo. Taki podział sprawia, że czytelnik nie mógł wypożyczyć podręcznika, a słownik, którego szukał, był umieszczony nie np. w księgozbiorze podręcznym, ale w bibliotecznym magazynie.

Księgarnie internetowe również mają problem z odpowiednim zaszeregowaniem wrocławskich publikacji. „Literatura i Kultura Popularna” nie

${ }^{24}$ Informację o dofinansowaniu zamieszczono na stronie redakcyjnej publikacji M. Gołaczyńskiej, dz. cyt.

25 J. Fras, Dziennikarski warsztat językowy, Wrocław 2005, s. 147.

26 I. Kamińska-Szmaj, Agresja językowa w życiu publicznym. Leksykon inwektyw politycznych 1918-2000, Wrocław 2007, s. 370. 
są wyszukiwane jako seria „Act”, ale wyłącznie pod swoim tytułem. Wyszukiwarki nie odszukują również serii „Acta Universitatis Wratislaviensis", jednak z łatwością można odnaleźć tom monograficzny po tytule.

„Acta” odbiegają od definicyjnych standardów wydawania serii. Trudno znaleźć w nich wspólne punkty. Wydawnictwo również nie pomaga $w$ interpretacji formalnej swoich publikacji, na stronach redakcyjnych nie zamieszcza jednoznacznego podziału tytułów. Oficyna nie położyła też nacisku na próby ujednolicenia pozycji, postawiono natomiast na różnorodność w seryjności. Wydawcy nie podeszli do tych publikacji w sposób marketingowy - gdyby książki wydawano w szacie graficznej, do której można by dopasować jakiś klucz, odbiorca mający już wcześniejsze tomy, chcąc mieć komplet, zaopatrywałby się w kolejne. Przy takiej polityce wydawnictwa opuszczenie dwóch czy też większej liczby egzemplarzy w serii nie robi kupującemu różnicy.

\section{Podsumowanie}

Seria serii jest nierówna, nie znaczy to jednak, że wydawnictwa te seSriami nie są. Wielotorowe podejście do wydawania jest związane z tematem i typem ukazujących się publikacji. Seria literacka jest inną serią niż naukowa. Ma innego odbiorcę, inny cel i różne strategie marketingowe, a także inne środki finansowania, co przecież jest bardzo ważne przy wydawaniu seryjnym publikacji, zwłaszcza gdy oficynie zależy na regularności ukazujących się kolejnych seryjnych tomów. Ważny jest też dobór materiału. Kiedy wydawana jest seria historycznoliteracka, wydawca opracowuje tekst już istniejący, wykorzystując dzieła z historii literatury. Jednak gdy publikowana jest seria naukowa, materiał powstaje w czasie cyklu wydawniczego określonego tytułu, co też może wpływać i bardzo często wpływa na periodyczność ukazujących się prac. Koncepcji wydawniczych jest tyle ile wydawnictw. Strategii wydawania serii również. Jedne są wzorem swojej seryjności - ukazują się regularnie i bez problemu można je zidentyfikować, wśród innych zaś seryjności trzeba się głęboko dopatrywać. 
Periodicity and non-periodicity of series editions

Abstract

Publishing the book series is one of the strategy which could be accepted by a publisher when considering series of scripts combined with common range. Year 1989, when Polish economy has transferred to free-market system, was a time when Polish book market has been liberated as well. In these circumstances we could have observed multiplicity of published editions, there were many various publications which have been much more difficult to classify than in the past years. Above article is trying to analyze three publishing series: "Klasyka Mniej Znana”, "Literatura i Kultura Popularna”, "Acta Universitatis Wratislaviensis". First one is literary edition, second one is sort of scientific edition and last one is appeared as an unique research edition which has been advertising periodically in volumes. 